\title{
Solar Radiation and Vitamin D: Mitigating Environmental Factors in Autoimmune Disease
}

\author{
Gerry K. Schwalfenberg \\ Department of Family Medicine, University of Alberta, Suite No. 301, 9509-156 Street, Edmonton, AB, Canada T6G 2 M7 \\ Correspondence should be addressed to Gerry K. Schwalfenberg, gschwalf@telus.net
}

Received 3 July 2011; Revised 29 November 2011; Accepted 13 December 2011

Academic Editor: Robin Bernhoft

Copyright ( $) 2012$ Gerry K. Schwalfenberg. This is an open access article distributed under the Creative Commons Attribution License, which permits unrestricted use, distribution, and reproduction in any medium, provided the original work is properly cited.

\begin{abstract}
This paper looks at the environmental role of vitamin $\mathrm{D}$ and solar radiation as risk reduction factors in autoimmune disease. Five diseases are considered: multiple sclerosis, type 1 diabetes, rheumatoid arthritis, autoimmune disease of the thyroid, and inflammatory bowel disease. Clinical relevant studies and factors that may indicate evidence that autoimmune disease is a vitamin D-sensitive disease are presented. Studies that have resulted in prevention or amelioration of some autoimmune disease are discussed. An example of the utility of supplementing vitamin D in an unusual autoimmune disease, idiopathic thrombocytic purpura, is presented.
\end{abstract}

\section{Introduction}

After cardiovascular disease and cancer, autoimmune diseases, taken as a group, are the third leading cause of morbidity and mortality in the industrialized world [1]. There are more than eighty defined autoimmune diseases [2] known in humans. A multifactorial interaction between genetic predisposition, immunologic, hormonal and environmental stimuli contributes to the development of autoimmune disease [3]. Agents that may trigger autoimmune disease include infections, vaccine immunogens, adjuvants used to increase immune response, smoking and stress, and so forth as outlined in the literature [4]. (See Table 1). The prevalence of some autoimmune diseases may be as high as $5 \%$ in the general population [5]. Little is known about mitigating factors until recently. Evidence that autoimmune disease may be a vitamin $\mathrm{D}$-sensitive disease comes from many studies. Solar radiation (UVR) and vitamin $\mathrm{D}$ have been shown to inhibit the induction of a number of autoimmune diseases in animal models [6-8]. (See Table 2). Autoimmune disease should vary by season, temperature, level of ultraviolet irradiance, latitude, race or skin color, BMI, physical activity, and vitamin D supplementation, if it is a vitamin $\mathrm{D}$-sensitive process.
This paper will discuss the interaction between the host, the agent, and the environment as depicted in Figure 1. The environmental factor being considered is UVB radiation induced vitamin D or supplemental vitamin D. Five autoimmune diseases will be discussed. Multiple sclerosis, type 1 diabetes, rheumatoid arthritis, autoimmune disease of the thyroid, and inflammatory bowel disease.

At the end of this paper, an example of the utility of vitamin $\mathrm{D}$ in idiopathic thrombocytic purpura, another autoimmune disease, is discussed.

\section{A Brief Overview of Vitamin D and Its Potential Role in Autoimmune Disease}

Vitamin D deficiency is common in latitudes far from the equator $[10,11]$, and solar abstinence has been in vogue for the past few decades for fear of inducing skin cancer. Sun exposure (a minimal erythemal dose with full body exposure) can rapidly produce 10,000 or more units of vitamin D [12], and toxicity has not been ascribed to this method of achieving normal vitamin D status. Vitamin D used orally at 10,000 IU a day for several months does not cause toxicity [13]. Vitamin D is a secosteroid hormone 
TABLE 1: Agents that trigger autoimmune disease.

Infections

Vaccine immunogens

Adjuvants used to enhance immune response

Birth control, pregnancy

Smoking

Stress

Adapted from $[3,4]$.

TABle 2: Autoimmune diseases that are inhibited by $1,25(\mathrm{OH}) 2 \mathrm{D}$ in animal studies [6].

Autoimmune encephalomyelitis

Collagen-induced arthritis

Inflammatory bowel disease

Type 1 diabetes

Systemic erythematosus

Thyroiditis

Lyme arthritis

Rheumatoid arthritis

Multiple sclerosis

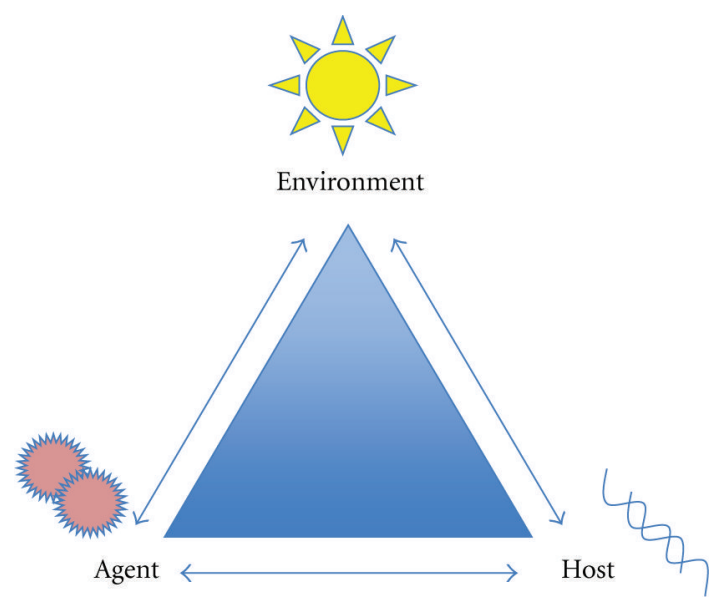

Figure 1: Autoimmune disease causation triangle. Adapted from [9]. Used with permission.

available in some foods and supplements or produced in the skin from 7-dehydrocholesterol after exposure to ultraviolet B light. The resulting previtamin D is then hydroxylated in the liver to hydroxyvitamin $\mathrm{D}(25(\mathrm{OH}) \mathrm{D})$ and further hydroxylated in the kidney to 1,25-dihydroxyvitamin D $\left(1,25(\mathrm{OH})_{2} \mathrm{D}\right)$ which is the active hormone involved in calcium absorption in the gut. Circulating $25(\mathrm{OH}) \mathrm{D}$ (which is considered the measure of vitamin $\mathrm{D}$ adequacy) may also be used as substrate in many cells to locally produce $\left(1,25(\mathrm{OH})_{2} \mathrm{D}\right)$, the active hormone, via the CYP27B1 $(1 \alpha-$ hydroxylase) enzyme and is inactivated by the CYP24A (24hydroxylase) enzyme [14]. The classical role of vitamin $\mathrm{D}$ is to regulate calcium homeostasis [15]. Short latency diseases, such as rickets and osteomalacia, can be cured with $25(\mathrm{OH}) \mathrm{D}$ levels $>25 \mathrm{nmol} / \mathrm{L}$. In a long-latency disease, such as osteoporosis, levels of $25(\mathrm{OH}) \mathrm{D}>50 \mathrm{nml} / \mathrm{L}$ have been shown to reduce fractures.

In the last twenty years, the importance of vitamin $\mathrm{D}$ in the role of a hormone has been shown to influence numerous other diseases including cancer by increasing apoptosis in cancer cells and protecting DNA in normal cells [16]. Its effect on the immune system and infections is only beginning to be understood, and much higher doses of vitamin D may be needed to be effective in combating viruses, bacteria, and fungi [17]. Vitamin D is now recognized to be crucial in betadefensin production in Crohn's disease [18].

The role in regulating the immune system in regards to self-tolerance and autoimmunity begins with an understanding of the impact of vitamin D on our genes. Research is showing that there are 2776 "binding sites" on the human genome to which vitamin D attaches, with at least 229 genes associated with Crohn's disease and type 1 diabetes [19]. Many of the sites are concentrated around genes linked to autoimmune conditions as described in this paper. Beyond this, vitamin D suppresses autoimmune disease pathology by regulating differentiation and activity of CD4+ $\mathrm{T}$ cells resulting in a more balanced $\mathrm{T} 1 / \mathrm{T} 2$ response favoring less development of self-reactive $\mathrm{T}$ cells and autoimmunity [2].

\section{Multiple Sclerosis}

In regards to the host, it is known that only $30 \%$ of monozygotic twin pairs eventually get multiple sclerosis (MS) leading us to believe that exposure to one or more environmental risk factors is necessary for the development of MS [20]. Recently, two large genomic studies have confirmed the unambiguous associations with the DRB1 and DQB alleles of the human leukocyte antigen class II region and susceptibility to MS [21]. 
Multiple environmental factors may play a role in multiple sclerosis. An example is the Epstein-Barr virus infections [22]. The risk of developing multiple sclerosis following infectious mono is increased significantly for more than 30 years following infection [23]. Even after 10 years following infection, the risk has been defined as at least four-fold [24]. Sunlight and vitamin D may be protective, and MS demonstrates vitamin D sensitivity [25].

Evidence shows that MS correlates positively with higher latitude, with latitudes $>37.5$ degrees from the equator having significantly higher rates of MS [26-29]. The time of the first exacerbation after disease onset shows seasonal variation with $76 \%$ of exacerbations occurring in winter [30]. However, in another study, the likelihood and intensity of MS disease activity correlated positively with spring and summer (March to August) along with increased temperature and UVR [31]. Relapses of MS have a biphasic pattern with peaks in early spring when vitamin D levels are low and late fall when levels are declining [32]. MS also correlates positively with season of birth, with a significantly higher incidence of MS in those born in May, corresponding to low vitamin $\mathrm{D}$ levels in the winter months prior to giving birth [33]. As well, MS correlates inversely with altitude, with higher elevation (>2000 Meters) receiving more intense solar radiation having lower rates of MS [34]. Adiposity has been associated with lower vitamin D levels $[35,36]$, and a higher body mass index (BMI) has been associated with higher incidence of MS in adolescent women but not in adult women [37]. Multiple sclerosis correlates positively with skin color where sun avoidance is more likely (fair skin phenotype) [38]. In Norway, the intake of vitamin D in costal communities is estimated to be three times the average intake of those living inland and this is inversely associated with MS [39].

There are only a limited number of trials currently available in humans. An American study of more than 187,000 women followed for 10-20 years showed promising results with females taking at least $400 \mathrm{IU}$ of supplemental vitamin D daily. The risk of developing MS was decreased by $40 \%$ [40]. Vitamin $\mathrm{D}_{3}$ has been used safely in MS patients at high doses from 28 to 280, $000 \mathrm{IU}$ per week. Mean levels of $25(\mathrm{OH}) \mathrm{D}$ rose to a mean of $385 \mathrm{nmol} / \mathrm{L}$ without causing hypercalcemia after being given the highest dose. Disease progression and activity were not affected in this study, but the number of gadolinium-enhancing lesions per patient assessed by nuclear magnetic brain scan was significantly reduced [41]. The highest dose in this study was only used for the last 6 weeks of the study, and longer-term use at this dose may risk significant toxicity in some patients. A trial using high-dose vitamin $\mathrm{D}_{2}$ to achieve $25(\mathrm{OH}) \mathrm{D}$ levels of $130-195 \mathrm{nmol} / \mathrm{L}$ did not reduce MRI lesions in relapsing remitting multiple sclerosis [42]. In a recently reported trial using escalating doses up to $40,000 \mathrm{IU}$ of vitamin $\mathrm{D}_{3}$ for 28 weeks followed by 10,000 IU daily for 12 weeks, there were no significant adverse events and there appeared to be significantly less progression of disability in the treatment group [43].

\section{Type 1 Diabetes}

As with multiple sclerosis only about $34 \%$ of identical twins will develop type 1 diabetes [44]. Thus, exposure to other environmental stimuli must play an important role.

In the past rubella infection has been implicated as an inducer of type I diabetes. Several studies now indicate infection with enteroviruses seem to be linked to the induction of islet cell destruction and development of autoantibodies $[45,46]$. Stress in the mother during pregnancy has been associated with elevated islet autoantibodies in cord blood [47].

The following is a summary of the evidence that type 1 diabetes is a vitamin D-sensitive disease. Type I diabetes varies by latitude with higher incidence in latitudes further from the equator (both north or south of the equator) except where local weather may influence this [48]. A yearly cyclical pattern (consistent over 20 years) of type 1 diabetes in Newfoundland reveals a peak incidence in winter [49]. Greater exposure to erythemal UVB radiation is negatively correlated with the incidence of type 1 diabetes [50]. The birth months of March to June correlate with an increased incidence of diabetes in Britain with prenatal exposure to low vitamin $\mathrm{D}$ levels during the winter months [51]. The average yearly temperature also correlates inversely with the incidence of type 1 diabetes [52]. Higher BMI as well as lower plasma levels of $25(\mathrm{OH}) \mathrm{D}$ correlate directly with development of type 1 diabetes in young adults $[53,54]$. Maternal vitamin D levels have been shown to correlate inversely to the presence of islet autoantibodies in the offspring [55]. Supplementation of vitamin D in early childhood appears to reduce the chances of developing type 1 diabetes [56].

There is a large body of evidence showing that lack of vitamin D early in life is linked to the development of type 1 diabetes. Vitamin D used at a dose of 2000 IU in infants has been shown to reduced the subsequent development of type 1 diabetes over the next thirty years by 78 percent [57]. The use of cod liver oil in pregnancy and during the first year of life has been shown to reduce the risk of childhood onset type 1 diabetes. However, it was not possible to determine if vitamin $\mathrm{D}$, omega-3 fatty acids, or the combination contributed to this result $[58,59]$. The use of $400 \mathrm{IU}$ of vitamin $\mathrm{D}$ has not been shown to reduce diabetes incidence [60]. In Finland the use of $2000 \mathrm{IU}$ of vitamin D in children was recommended from 1964 to 1975 when it was lowered to $1000 \mathrm{IU}$ of vitamin D supplementation with a small increase in type 1 diabetes incidence following this recommendation. A further reduction to the use of 400 IU of vitamin D in 1992 correlates with a significant rise in the incidence of type 1 diabetes since then [61]. A meta-analysis and systematic review on the use of vitamin D supplementation in early childhood in type 1 diabetes showed that the risk of developing type 1 diabetes was significantly reduced in infants with supplementation [56]. The pooled odds ratio was 0.71 (a CI of 0.60 to 0.84 ), and there was evidence of a dose-response effect showing a lower risk of developing type 1 diabetes with the use of higher amounts of vitamin D. In regards to sun exposure, 
the incidence of type 1 diabetes approaches zero in areas with high levels of UVB irradiance [48].

\section{Rheumatoid Arthritis (RA)}

The maximum genetic contribution indicated by studies on monozygotic twins is about $15 \%$ when it comes to rheumatoid arthritis (RA) and systemic lupus erythematosus (SLE) [62]. The HLA-DRB1 gene represents the major determinant of genetic predisposition to RA [63].

The association of infections and RA is still being debated in the literature. There is some evidence that RA-like diseases may result from the immunologic interaction between the host and bacterial peptidoglycans. Several agents relative to RA have been entertained such as heat shock proteins, bacterial IgG FC-binding proteins and rheumatoid factors [64]. Retroviruses and enteropathogenic bacteria continue to be intensively discussed candidates [65]. IgM antibodies to parvovirus B19 indicating recent infection correlate with juvenile idiopathic arthritis [66]. Certainly smoking has been cited as being a major risk factor both in RA and SLE as well as a risk factor for RF-positive and anti-citrulline antibody titers [67]. The risk only diminishes slowly after several years of cessation of smoking.

Increasing latitude in the northern hemisphere has been shown to correlate with increased risk of RA providing some support for a beneficial role of UVR [68]. Patients with undifferentiated connective tissue diseases have a seasonal variance in $25(\mathrm{OH}) \mathrm{D}$ levels, being significantly lower than controls in corresponding seasons [69]. Seasonal variations showed lower disease activity with higher $25(\mathrm{OH}) \mathrm{D}$ levels [70]. It appears that rheumatoid arthritis does not have association with month of birth [71]. Rheumatoid arthritis activity is inversely related to $25(\mathrm{OH}) \mathrm{D}$ levels [72]. Rheumatoid arthritis severity is associated positively with BMI with a high BMI having a greater risk of low 25(OH)D levels [73]. The incidence of arthritis in children is highest in Caucasian versus East Indian, First Nations as well as African American $[74,75]$. The Iowa Women's Health Study showed an inverse association of vitamin D intake and rheumatoid arthritis [76] There was a 34\% reduction in the development of rheumatoid arthritis with greater vitamin D intake. Women using a multivitamin with $400 \mathrm{IU}$ of vitamin D reduced their risk of developing RA by 40\% [76]. An open-label study using a high-dose vitamin D3 analogue resulted in improvement of symptoms in RA in $89 \%$ of patients with $45 \%$ of patients entertaining a complete remission [77].

\section{Autoimmune Disease of the Thyroid}

Autoimmune disease of the thyroid (AITD) is very prevalent with $5 \%$ of the population being affected. This includes both Hashimoto's (HT) and Graves' disease (GD) [5]. Several susceptibility genes for AITD have been identified, and it has been estimated that up to $80 \%$ may be attributable to genes [78]. However, the concordance rates in monozygotic twins is about $30-60 \%$, while dizygotic twins is only $3-9 \%$, and up to $50 \%$ of siblings of patients with GD having thyroid autoantibodies [79]. Thus, environmental factors contribute significantly to the expression of the disease.

Environmental factors are numerous and include iodine excess and deficiency, selenium deficiency, oral contraceptive use, parity, low birth weight, seasonal variation, allergy, smoking, radiation, viral and bacterial infections, and so forth [78]. Overall, data suggests that cumulative cigarette consumption significantly increases the risk of developing AITD [80]. Hashimoto's thyroiditis is associated with vitamin D insufficiency with AITD patients having significantly lower levels than controls [81, 82]. In AITD 72\% of patients had $25(\mathrm{OH}) \mathrm{D}$ levels less than $25 \mathrm{nmol} / \mathrm{L}$ compared to $30.6 \%$ in healthy individuals. In patients with Hashimoto's thyroiditis, $79 \%$ had levels less than $25 \mathrm{nmol} / \mathrm{L}$ compared to $52 \%$ in normal controls.

The lowest incidence of AIDT disease was found in July to October (when vitamin D levels are high), and the highest incidence was in January to March when vitamin D levels tend to be low in the northern hemisphere [83]. The incidence of diagnosis of thyrotoxicosis is highest in May just after the winter when vitamin $\mathrm{D}$ levels are beginning to rise; however, this may also be a reflection of feeling hot with increasing ambient temperatures [84]. There is no information on altitude or temperature. Vitamin D levels are lower in AITD patients than in normal controls and supplementation is recommended [82]. There are presently no studies using vitamin D as an intervention in AITD; however, supplementation has been suggested.

\section{Inflammatory Bowel Disease}

In regards to genetic predisposition, a national German study has shown that concordance rates in monozygotic twins are about 35\% for Crohn's disease (CD) and 16\% for ulcerative colitis (UC), showing that environmental factors play a significant role in inflammatory bowel disease (IBD) [85].

An environmental trigger shown to increase the risk of development of $\mathrm{CD}$ is smoking. Many other triggers have been proposed such as infectious gastroenteritis, oral contraceptives, invasive E. coli, and antibiotics [86]. Vitamin D insufficiency is associated with inflammatory bowel disease $[87,88]$. In another study $25(\mathrm{OH}) \mathrm{D}$ levels were lower in those with severe disease activity and less sun exposure [89].

A study in France has shown that there is an increasing incidence of UC with northern latitude [90]. Smaller studies did not show any seasonal pattern for IBD, but a larger study showed an increase incidence in those born in the first half of the year [91] while others show an increased incidence of exacerbations in summer. There is no information on altitude or temperature. Obesity is more common in Crohn's disease at the time of diagnosis [92]. Vitamin D deficiency is very prevalent in IBD [93] and the effects of low-dose supplementation are poor [94]. A clinical trial using $1200 \mathrm{IU}$ of vitamin $\mathrm{D}_{3}$ for 12 months resulted in a reduced risk of relapse from $29 \%$ to $13 \%$, although this did not quite reach statistical significance [95]. Other trials are currently under way. 
A striking example in which vitamin D made a significant change in morbidity in another autoimmune disease follows.

\section{A Case History and Discussion of the Benefit of Vitamin D in Idiopathic Thrombocytopenic Purpura in an Adult}

Idiopathic thrombocytopenic purpura (ITP) is an autoimmune disease in which most patients have antibodies to specific membrane glycoprotein's on platelets. The incidence in adults is about 33/1,000,000 [96] of which about 10/1,000,000 become refractory. Spontaneous remission is uncommon in adults. The 5-year mortality rate is significantly elevated in adults over the age of $60(47.8 \%)$ versus those below 40 years of age $(2.2 \%)$, respectively. The most serious complication is hemorrhage of which intracranial hemorrhage is the most significant.

Vitamin D has been shown to improve outcomes and prevent some autoimmune diseases if taken early in life as discussed previously in the paper.

Treatment of ITP usually includes medications such as corticosteroids, splenectomy danazol, and various immune suppressant therapies [97]. The use of vitamin $\mathrm{D}_{3}$ in ITP has not been described in the literature.

This example describes a patient who had refractory ITP who has been treated in the past with a splenectomy, danazol, and prednisone rescue during intercurrent illness. A review of the history of this case revealed a 48-year-old female who was found to have a very low platelet count in 1998, which remained persistent over time. After consultation with a hematologist, the diagnosis of ITP was made. Her platelets continued to drop so she had a splenectomy, which improved her platelet count, but it never achieved normal. Despite the use of danazol, her platelet count never normalized. She had frequent episodes of low platelets as low as $8 \times 10^{9}$ with intercurrent illnesses such as colds or flus. In 2006 she was found to have an inadequate level of $25(\mathrm{OH}) \mathrm{D}$ of $65 \mathrm{nmol} / \mathrm{L}$. Her platelet count at that time was $8 \times 10^{9}$ after a viral illness. She was treated successfully with a tapering dose of Prednisone. She was started on vitamin $\mathrm{D}_{3} 2000$ IU daily after this episode and during the next two years while she was on this dose she did not have any flus or colds and her platelet count never fell below $44 \times 10^{9}$ and was usually from 70 to $80 \times 10^{9}$. This was quite out of the normal for her since she had at least one low episode a year. After being on this dose for two years, a neighbor in her building where she resided suggested that she was going to become toxic on this dose and she stopped her vitamin D. About three months later, she again had an upper respiratory infection (URI) and her platelets dropped only to $50 \times 10^{9}$ and she was started on prednisone with recovery of her platelets to $140 \times 10^{9}$. She was seen after this, and it was recommended that she resume her vitamin $\mathrm{D}_{3}$ at a higher dose of $4000 \mathrm{IU}$ daily. She was feeling quite well, and her platelets remained above 70 and continued to rise so she discontinued her danazol. Again, she had no further episodes of flu or colds for the next two years and her platelets did not drop below 70. Her vitamin D level on this dose was $88 \mathrm{nmol} / \mathrm{L}$ after 4 months. She phoned one day that she was sick with a URI, and it was suggested that she take 10,000 IU of vitamin D for a 3 days and have her platelets checked. She had her platelets checked after being on this dose for two days, and they were in the normal range much higher than they had been for years. The platelet count was $248 \times 10^{9}$. Her vitamin D level was $99 \mathrm{nmol} / \mathrm{L}$ at this time. She continues on the $4000 \mathrm{IU}$ vitamin $\mathrm{D}$, and she continues off the danazol and remains well. Her latest platelet count was $318 \times 10^{9}$.

This case presents a significant response to vitamin $\mathrm{D}_{3}$ in ITP. As well, it demonstrates a recurrent failure with lack of vitamin D and restoration of a normal platelet count on a higher dosing of vitamin $\mathrm{D}_{3}$, which did not result in toxicity. The vitamin $\mathrm{D}_{3}$ rescue with $10,000 \mathrm{IU}$ of vitamin $\mathrm{D}_{3}$ appeared to result in a similar response as that of prednisone used in past treatments over the years. ITP has been shown to have spontaneous remission in some people; however, it is uncommon in older patients. Is it possible that restoration of vitamin D levels results in some of these cases of spontaneous resolution? At this time this is not known. Restoring vitamin $\mathrm{D}$ to a level that is safe appears to be sensible supportive therapy.

Restoration of adequate platelets has never been demonstrated with repletion of inadequate vitamin D levels in the literature. Certainly in this example, vitamin $\mathrm{D}_{3}$ restoring reasonable platelet levels and reducing the number of infections is most fascinating. The reduction in platelet levels with removal of vitamin $\mathrm{D}_{3}$ with restoration of normal levels with an increased dose of vitamin $\mathrm{D}_{3}$, as well as rescue with higher levels of vitamin $\mathrm{D}_{3}$, is furthermore more intriguing. More studies would be warranted to demonstrate the benefit of adequate $25(\mathrm{OH}) \mathrm{D}$ levels in ITP.

\section{Discussion and Conclusion}

This paper outlines a number of autoimmune diseases that show vitamin $\mathrm{D}$ sensitivity as provided by supplementation, UVR, or other factors. These factors have been summarized in Table 3. At this time the research on the role of vitamin $\mathrm{D}$ in autoimmune disease is not conclusive, and much of the data comes from epidemiologic or case control studies. However, the evidence is increasingly pointing towards a significant role of vitamin $\mathrm{D}$ in reducing the incidence and burden of autoimmune diseases.

The link between various autoimmune diseases and vitamin $\mathrm{D}$ in various ecological, population, and case control studies is summarized in Table 4. Interventional studies when available have been cited throughout this paper. Although not all linkages are positive in each disease, the ones that have been studied the most, such as MS and type 1 diabetes, are quite striking. Studies done in type 1 diabetes were done in infants, and supplementation during the prenatal and first year of life may result in a significant reduction of morbidity later in life. Vitamin D may very well be a significant factor in preventing the loss of tolerance to self and resultant autoimmune disease.

Population studies have shown consistently in many "northern" countries (i.e., Canada) that the majority of the 
TABLE 3: Autoimmunity and factors that relate to vitamin D-sensitive diseases.

\begin{tabular}{|c|c|c|c|c|c|}
\hline $\begin{array}{l}\text { Parameters relating to } \\
\text { vitamin D }\end{array}$ & $\begin{array}{l}\text { Multiple } \\
\text { Sclerosis }\end{array}$ & $\begin{array}{l}\text { Type } 1 \\
\text { diabetes }\end{array}$ & $\begin{array}{l}\text { Rheumatoid } \\
\text { arthritis }\end{array}$ & $\begin{array}{c}\text { Autoimmune } \\
\text { disease of } \\
\text { thyroid }\end{array}$ & $\begin{array}{l}\text { Inflammatory } \\
\text { bowel disease }\end{array}$ \\
\hline Incidence seasonality & + & + & + & + & - \\
\hline Seasonality of birth & + & + & - & + & + \\
\hline Latitude & + & + & + & $\mathrm{N} / \mathrm{A}$ & + \\
\hline Altitude & + & N/A & N/A & N/A & N/A \\
\hline Temperature & + & + & N/A & + & N/A \\
\hline BMI & + & + & + & N/A & + \\
\hline Race (skin tone) & + & + & - & $\mathrm{N} / \mathrm{A}$ & N/A \\
\hline UV radiance & + & + & + & + & + \\
\hline Vitamin D intake & + & + & + & + & + \\
\hline
\end{tabular}

Evidence from studies listed in the paper for positive correlation of vitamin D-sensitive parameters in each disease. +: positive correlation, -: negative correlation, N/A: information lacking.

TABLE 4: Human studies in autoimmune disease.

\begin{tabular}{|c|c|c|}
\hline Autoimmune disease & Study design $(N)$ & Results \\
\hline \multirow[t]{4}{*}{ Multiple sclerosis } & $\begin{array}{l}\text { Prospective cohort studies NHS, NHS II } \\
\text { supplementation of vitamin D }(N=187,365)[40]\end{array}$ & $\begin{array}{l}40 \% \text { reduction in developing MS with } \\
\text { supplementation of } 400 \mathrm{IU} \text { vitamin D }\end{array}$ \\
\hline & $\begin{array}{l}\text { Open label progressive supplementation of vitamin D } \\
(N=12)[41]\end{array}$ & $\begin{array}{l}\text { The number of gadolinium-enhancing } \\
\text { lesions was reduced }\end{array}$ \\
\hline & $\begin{array}{l}\text { Randomized control using } 1000 \mathrm{IU} \text { versus } 6000 \mathrm{IU} \\
\text { daily of vitamin } \mathrm{D}_{2} \text { for } 6 \text { months }(N=23)[42]\end{array}$ & $\begin{array}{l}\text { Vitamin } \mathrm{D}_{2} \text { was not effective in reducing } \\
\text { MRI lesions in RRMS }\end{array}$ \\
\hline & Open-label randomized controlled trial $(N=49)[43]$ & $\begin{array}{l}8 \% \text { in the treatment group had worsening } \\
\text { disability versus } 38 \% \text { of patients in the } \\
\text { control group }\end{array}$ \\
\hline \multirow[t]{3}{*}{ Diabetes } & Birth cohort study $(N=12058)[57]$ & $\begin{array}{l}\text { Use of } 2000 \mathrm{IU} \text { had a reduced risk of } \\
\text { developing diabetes by } 78 \%\end{array}$ \\
\hline & $\begin{array}{l}\text { Newly diagnosed diabetic children from } 1980-2005 \\
(N=10737)[61]\end{array}$ & $\begin{array}{l}\text { Significant increase in incidence noted } \\
\text { after reduction in vitamin D intake rec- } \\
\text { ommendation (decreased daily recom- } \\
\text { mendation from } 1000 \mathrm{IU} \text { to } 400 \mathrm{IU} \text { ) }\end{array}$ \\
\hline & $\begin{array}{l}\text { Meta-analysis of supplementation of vitamin D in } \\
\text { infants [56] }\end{array}$ & $\begin{array}{l}29 \% \text { reduction in risk of developing type } \\
1 \text { diabetes }\end{array}$ \\
\hline \multirow[t]{2}{*}{ Rheumatoid arthritis } & $\begin{array}{l}\text { Prospective cohort study dietary and supplement } \\
\text { vitamin D intake }(N=29,368)[76]\end{array}$ & $\begin{array}{l}34 \% \text { reduction in developing } \mathrm{RA} \text { in the } \\
\text { supplement group }>400 \mathrm{IU} \text { vitamin } \mathrm{D}\end{array}$ \\
\hline & $\begin{array}{l}\text { Open-label trial using high-dose oral alphacalcidiol } \\
\text { therapy, }(N=19)[77]\end{array}$ & $\begin{array}{l}\text { Result in a positive effect on disease } \\
\text { activity in } 89 \% \text { of patients }\end{array}$ \\
\hline $\begin{array}{l}\text { Autoimmune thyroid } \\
\text { disease }\end{array}$ & None available to date & \\
\hline Crohn's disease & $\begin{array}{l}\text { Randomized double-blind placebo-controlled study } \\
(N=94)[95]\end{array}$ & $\begin{array}{l}1200 \mathrm{IU} \text { of vitamin } \mathrm{D}_{3} \text { reduced the num- } \\
\text { ber of relapses in the treatment group by } \\
\text { more than } 50 \% \text { during a } 1 \mathrm{yr} \text { study }\end{array}$ \\
\hline
\end{tabular}

population is vitamin $\mathrm{D}$ deficient. Knowing that a large proportion of the population do not have adequate levels of vitamin $\mathrm{D}$, it may be prudent to restore levels to $>100 \mathrm{nmol} / \mathrm{L}$ for optimum function of the immune system. $2000 \mathrm{IU}$ of vitamin $\mathrm{D}_{3}$ has been shown to improve vitamin $\mathrm{D}$ status and achieve these levels in about $80 \%$ of patients [98]. This may decrease autoimmune disease incidence. Increasing vitamin $\mathrm{D}$ intake would benefit the general population with better bone health and prevention of cancer and infectious diseases.
An estimate in the savings in healthcare expenditures with restoration of adequate vitamin $\mathrm{D}$ is in the billions of dollars $[99,100]$ These estimates include only a few of the many autoimmune diseases that vitamin D may mitigate. Further studies are warranted in addressing autoimmune disease and vitamin $\mathrm{D}$. These studies should use vitamin $\mathrm{D}_{3}$ since, as in the above outlined studies, vitamin $\mathrm{D}_{2}$ was not effective and the latest evidence suggests that only vitamin $\mathrm{D}_{3}$, not vitamin $\mathrm{D}_{2}$, improves mortality [101]. 


\section{References}

[1] M. Harel and Y. Shoenfeld, "Predicting and preventing autoimmunity, myth or reality?" Annals of the New York Academy of Sciences, vol. 1069, pp. 322-345, 2006.

[2] M. T. Cantorna and B. D. Mahon, "Mounting evidence for vitamin $\mathrm{D}$ as an environmental factor affecting autoimmune disease prevalence," Experimental Biology and Medicine, vol. 229, no. 11, pp. 1136-1142, 2004.

[3] V. Molina and Y. Shoenfeld, "Infection, vaccines and other environmental triggers of autoimmunity," Autoimmunity, vol. 38, no. 3, pp. 235-245, 2005.

[4] J. F. de Carvalho, R. M. Pereira, and Y. Shoenfeld, "The mosaic of autoimmunity: the role of environmental factors," Frontiers in Bioscience, vol. 1, pp. 501-509, 2009.

[5] E. M. Jacobson and Y. Tomer, "The genetic basis of thyroid autoimmunity," Thyroid, vol. 17, no. 10, pp. 949-961, 2007.

[6] E. Ginanjar, Sumariyono, S. Setiati, and B. Setiyohadi, "Vitamin D and autoimmune disease," Acta Medica Indonesiana, vol. 39, no. 3, pp. 133-141, 2007.

[7] M. Cutolo, K. Otsa, M. Uprus, S. Paolino, and B. Seriolo, "Vitamin D in rheumatoid arthritis," Autoimmunity Reviews, vol. 7, no. 1, pp. 59-64, 2007.

[8] A. L. Ponsonby, R. M. Lucas, and I. A. F. Van Der Mei, "UVR, vitamin D and three autoimmune diseases-multiple sclerosis, type 1 diabetes, rheumatoid arthritis," Photochemistry and Photobiology, vol. 81, no. 6, pp. 1267-1275, 2005.

[9] F. Garland, Powerpoint presentation: Can Diabetes Be Prevented with Vitamin D? Department of Family and Preventative Medicine UCSD School of Medicine, 2008.

[10] G. Schwalfenberg, "Not enough vitamin D: health consequences for Canadians," Canadian Family Physician, vol. 53, no. 5, pp. 841-854, 2007.

[11] G. K. Schwalfenberg, S. J. Genuis, and M. N. Hiltz, "Addressing vitamin D deficiency in Canada: a public health innovation whose time has come," Public Health, vol. 124, no. 6, pp. 350-359, 2010.

[12] M. F. Holick, "Environmental factors that influence the cutaneous production of vitamin D," American Journal of Clinical Nutrition, vol. 61, supplement 3, pp. 638S-645S, 1995.

[13] J. N. Hathcock, A. Shao, R. Vieth, and R. Heaney, "Risk assessment for vitamin D," American Journal of Clinical Nutrition, vol. 85, no. 1, pp. 6-18, 2007.

[14] A. W. Norman, "From vitamin D to hormone D: fundamentals of the vitamin D endocrine system essential for good health," American Journal of Clinical Nutrition, vol. 88, no. 2, pp. 491S-499S, 2008.

[15] P. Lips, "Vitamin D physiology," Progress in Biophysics and Molecular Biology, vol. 92, no. 1, pp. 4-8, 2006.

[16] D. P. Hayes, "The protection afforded by vitamin D against low radiation damage," International Journal of Low Radiation, vol. 5, no. 4, pp. 368-394, 2008.

[17] G. K. Schwalfenberg, "A review of the critical role of vitamin $\mathrm{D}$ in the functioning of the immune system and the clinical implications of vitamin D deficiency," Molecular Nutrition and Food Research, vol. 55, no. 1, pp. 96-108, 2011.

[18] T. T. Wang, B. Dabbas, D. Laperriere et al., "Direct and indirect induction by 1,25-dihydroxyvitamin D3 of the NOD2/ CARD15-defensin $\beta 2$ innate immune pathway defective in crohn disease," Journal of Biological Chemistry, vol. 285, no. 4, pp. 2227-2231, 2010.

[19] S. V. Ramagopalan, A. Heger, A. J. Berlanga et al., "A ChIP-seq defined genome-wide map of vitamin D receptor binding: associations with disease and evolution," Genome Research, vol. 20, no. 10, pp. 1352-1360, 2010.

[20] J. Hillert, "The genetics of multiple sclerosis," Results and Problems in Cell Differentiation, vol. 51, pp. 1-19, 2010.

[21] G. Giovannoni and G. Ebers, "Multiple sclerosis: the environment and causation," Current Opinion in Neurology, vol. 20, no. 3, pp. 261-268, 2007.

[22] E. L. Thacker, F. Mirzaei, and A. Ascherio, "Infectious mononucleosis and risk for multiple sclerosis: a meta-analysis," Annals of Neurology, vol. 59, no. 3, pp. 499-503, 2006.

[23] T. R. Nielsen, K. Rostgaard, N. M. Nielsen et al., "Multiple sclerosis after infectious mononucleosis," Archives of Neurology, vol. 64, no. 1, pp. 72-75, 2007.

[24] S. V. Ramagopalan, W. Valdar, D. A. Dyment et al., "Association of infectious mononucleosis with multiple sclerosis," Neuroepidemiology, vol. 32, no. 4, pp. 257-262, 2009.

[25] M. P. Pender, "The essential role of Epstein-Barr virus in the pathogenesis of multiple sclerosis," Neuroscientist, vol. 17, no. 4, pp. 351-367, 2011.

[26] A. Ascherio and K. Munger, "Epidemiology of multiple sclerosis: from risk factors to prevention," Seminars in Neurology, vol. 28, no. 1, pp. 17-28, 2008.

[27] A. E. Handel, L. Jarvis, R. Mclaughlin, A. Fries, G. C. Ebers, and S. V. Ramagopalan, "The epidemiology of multiple sclerosis in Scotland: inferences from hospital admissions," PLoS ONE, vol. 6, no. 1, article e14606, 2011.

[28] J. S. Sloka, W. E. M. Pryse-Phillips, and M. Stefanelli, "The relation of ultraviolet radiation and multiple sclerosis in Newfoundland," Canadian Journal of Neurological Sciences, vol. 35, no. 1, pp. 69-74, 2008.

[29] J. G. McLeod, S. R. Hammond, and J. F. Hallpike, "Epidemiology of multiple sclerosis in Australia: with NSW and SA survey results," Medical Journal of Australia, vol. 160, no. 3, pp. 117-121, 1994.

[30] C. Bisgård, "Seasonal variation in disseminated sclerosis," Ugeskrift for Laeger, vol. 152, no. 16, pp. 1160-1161, 1990.

[31] D. S. Meier, K. E. Balashov, B. Healy, H. L. Weiner, and C. R. G. Guttmann, "Seasonal prevalence of MS disease activity," Neurology, vol. 75, no. 9, pp. 799-806, 2010.

[32] F. Salvi, I. Bartolomei, M. H. Smolensky et al., "A seasonal periodicity in relapses of multiple sclerosis? A single-center, population-based, preliminary study conducted in Bologna, Italy," BMC Neurology, vol. 10, article 105, 2010.

[33] C. J. Willer, D. A. Dyment, A. D. Sadovnick, P. M. Rothwell, T. J. Murray, and G. C. Ebers, "Timing of birth and risk of multiple sclerosis: population based study," British Medical Journal, vol. 330, no. 7483, pp. 120-123, 2005.

[34] J. F. Kurtzke, "On the fine structure of the distribution of multiple sclerosis," Acta Neurologica Scandinavica, vol. 43, no. 3, pp. 257-282, 1967.

[35] Y. Dong, N. Pollock, I. S. Stallmann-Jorgensen et al., "Low 25-hydroxyvitamin D levels in adolescents: race, season, adiposity, physical activity, and fitness," Pediatrics, vol. 125, no. 6, pp. 1104-1111, 2010.

[36] M. G. Bischof, G. Heinze, and H. Vierhapper, "Vitamin D status and its relation to age and body mass index," Hormone Research, vol. 66, no. 5, pp. 211-215, 2006.

[37] K. L. Munger, T. Chitnis, and A. Ascherio, "Body size and risk of MS in two cohorts of US women," Neurology, vol. 73, no. 19, pp. 1543-1550, 2009.

[38] T. Dwyer, I. Van Der Mei, A. L. Ponsonby et al., "Melanocortin 1 receptor genotype, past environmental sun exposure, and risk of multiple sclerosis," Neurology, vol. 71, no. 8, pp. 583-589, 2008. 
[39] K. Westlund, "Distribution and mortality time trend of multiple sclerosis and some other diseases in Norway," Acta Neurologica Scandinavica, vol. 46, no. 4, pp. 455-483, 1970.

[40] K. L. Munger, S. M. Zhang, E. O’Reilly et al., "Vitamin D intake and incidence of multiple sclerosis," Neurology, vol. 62, no. 1, pp. 60-65, 2004.

[41] S. M. Kimball, M. R. Ursell, P. O'Connor, and R. Vieth, "Safety of vitamin D3 in adults with multiple sclerosis," American Journal of Clinical Nutrition, vol. 86, no. 3, pp. 645651, 2007.

[42] M. S. Stein, Y. Liu, O. M. Gray et al., "A randomized trial of high-dose vitamin D2 in relapsing-remitting multiple sclerosis," Neurology, vol. 77, no. 17, pp. 1611-1618, 2011.

[43] J. M. Burton, S. Kimball, R. Vieth et al., "A phase I/II doseescalation trial of vitamin D3 and calcium in multiple sclerosis," Neurology, vol. 74, no. 23, pp. 1852-1859, 2010.

[44] P. Olmos, R. A'Hern, D. A. Heaton et al., "The significance of the concordance rate for Type 1 (insulin-dependent) diabetes in identical twins," Diabetologia, vol. 31, no. 10, pp. 747-750, 1988.

[45] H. Hyöty and K. Taylor, "The role of viruses in human diabetes," Diabetologia, vol. 45, no. 10, pp. 1353-1361, 2002.

[46] C. H. Williams, S. Oikarinen, S. Tauriainen, K. Salminen, H. Hyoty, and G. Stanway, "Molecular analysis of an echovirus 3 strain isolated from an individual concurrently with appearance of islet cell and IA-2 autoantibodies," Journal of Clinical Microbiology, vol. 44, no. 2, pp. 441-448, 2006.

[47] B. Lernmark, K. Lynch, and A. Lernmark, "Cord blood islet autoantibodies are related to stress in the mother during pregnancy," Annals of the New York Academy of Sciences, vol. 1079, pp. 345-349, 2006.

[48] S. B. Mohr, C. F. Garland, E. D. Gorham, and F. C. Garland, "The association between ultraviolet B irradiance, vitamin D status and incidence rates of type 1 diabetes in 51 regions worldwide," Diabetologia, vol. 51, no. 8, pp. 1391-1398, 2008.

[49] S. Sloka, M. Grant, and L. A. Newhook, "Time series analysis of ultraviolet B radiation and type 1 diabetes in Newfoundland," Pediatric Diabetes, vol. 9, no. 2, pp. 81-86, 2008.

[50] S. Sloka, M. Grant, and L. A. Newhook, "The geospatial relation between UV solar radiation and type 1 diabetes in Newfoundland," Acta Diabetologica, vol. 47, no. 1, pp. 73-78, 2010.

[51] P. M. Rothwell, A. Staines, P. Smail, E. Wadsworth, and P. McKinney, "Seasonality of birth of patients with childhood diabetes in Britain," British Medical Journal, vol. 312, no. 7044, pp. 1456-1457, 1996.

[52] H. K. Akerblom, D. J. Ballard, B. Bauman et al., "Geographic patterns of childhood insulin-dependent diabetes mellitus," Diabetes, vol. 37, no. 8, pp. 1113-1119, 1988.

[53] B. Littorin, L. Nyström, B. Gullberg et al., "Increasing body mass index at diagnosis of diabetes in young adult people during 1983-1999 in the Diabetes Incidence Study in Sweden (DISS)," Journal of Internal Medicine, vol. 254, no. 3, pp. 251256, 2003.

[54] B. Littorin, P. Blom, A. Schölin et al., "Lower levels of plasma 25-hydroxyvitamin D among young adults at diagnosis of autoimmune type 1 diabetes compared with control subjects: results from the nationwide Diabetes Incidence Study in Sweden (DISS)," Diabetologia, vol. 49, no. 12, pp. 2847-2852, 2006.

[55] L. Marjamäki, S. Niinistö, M. G. Kenward et al., "Maternal intake of vitamin D during pregnancy and risk of advanced beta cell autoimmunity and type 1 diabetes in offspring," Diabetologia, vol. 53, no. 8, pp. 1599-1607, 2010.
[56] C. S. Zipitis and A. K. Akobeng, "Vitamin D supplementation in early childhood and risk of type 1 diabetes: a systematic review and meta-analysis," Archives of Disease in Childhood, vol. 93, no. 6, pp. 512-517, 2008.

[57] E. Hyppönen, E. Läärä, A. Reunanen, M.-R. Järvelin, and S. M. Virtanen, "Intake of vitamin D and risk of type 1 diabetes: a birth-cohort study," The Lancet, vol. 358, no. 9292, pp. 1500-1503, 2001.

[58] L. C. Stene and G. Joner, "Use of cod liver oil during the first year of life is associated with lower risk of childhoodonset type 1 diabetes: a large, population-based, case-control study," American Journal of Clinical Nutrition, vol. 78, no. 6, pp. 1128-1134, 2003.

[59] L. C. Stene, J. Ulriksen, P. Magnus, and G. Joner, "Use of cod liver oil during pregnancy associated with lower risk of Type I diabetes in the offspring," Diabetologia, vol. 43, no. 9, pp. 1093-1098, 2000.

[60] S. S. Harris, "Vitamin D in type 1 diabetes prevention," Journal of Nutrition, vol. 135, no. 2, pp. 323-325, 2005.

[61] V. Harjutsalo, L. Sjöberg, and J. Tuomilehto, "Time trends in the incidence of type 1 diabetes in Finnish children: a cohort study," The Lancet, vol. 371, no. 9626, pp. 1777-1782, 2008.

[62] P. Jarvinen and K. Aho, "Twin studies in rheumatic disease," Seminars in Arthritis and Rheumatism, vol. 24, no. 1, pp. 1928, 1994.

[63] Y. Kochi, A. Suzuki, R. Yamada, and K. Yamamoto, "Genetics of rheumatoid arthritis: underlying evidence of ethnic differences," Journal of Autoimmunity, vol. 32, no. 3-4, pp. 158$162,2009$.

[64] R. L. Wilder and L. J. Crofford, "Do infectious agents cause rheumatoid arthritis?" Clinical Orthopaedics and Related Research, no. 265, pp. 36-41, 1991.

[65] A. Krause, T. Kamradt, and G. R. Burmester, "Potential infectious agents in the induction of arthritides," Current Opinion in Rheumatology, vol. 8, no. 3, pp. 203-209, 1996.

[66] B. Gonzalez, C. Larrañaga, O. León et al., "Parvovirus B19 may have a role in the pathogenesis of juvenile idiopathic arthritis," Journal of Rheumatology, vol. 34, no. 6, pp. 13361340, 2007.

[67] L. Klareskog, L. Padyukov, and L. Alfredsson, "Smoking as a trigger for inflammatory rheumatic diseases," Current Opinion in Rheumatology, vol. 19, no. 1, pp. 49-54, 2007.

[68] M. Cutolo, "Solar light effects on onset/relapses and circannual/circadian symptomatology in rheumatoid arthritis," Clinical and Experimental Rheumatology, vol. 21, no. 2, pp. 148-150, 2003.

[69] E. Zold, P. Szodoray, J. Gaal et al., "Vitamin D deficiency in undifferentiated connective tissue disease," Arthritis Research and Therapy, vol. 10, no. 5, article R123, 2008.

[70] M. Cutolo, K. Otsa, K. Laas et al., "Circannual vitamin d serum levels and disease activity in rheumatoid arthritis: Northern versus Southern Europe," Clinical and Experimental Rheumatology, vol. 24, no. 6, pp. 702-704, 2006.

[71] W. W. Buchanan, L. G. Gregoire, and H. M. Buchanan, "Month of birth and rheumatoid arthritis," The Lancet, vol. 2, no. 8557, p. 517, 1987.

[72] M. Rossini, S. Maddali Bongi, G. La Montagna et al., "Vitamin $\mathrm{D}$ deficiency in rheumatoid arthritis: prevalence, determinants and associations with disease activity and disability," Arthritis Research and Therapy, vol. 12, no. 6, article R216, 2010.

[73] G. Westhoff, R. Rau, and A. Zink, "Radiographic joint damage in early rheumatoid arthritis is highly dependent on body 
mass index," Arthritis and Rheumatism, vol. 56, no. 11, pp. 3575-3582, 2007.

[74] K. G. Oen and M. Cheang, "Epidemiology of chronic arthritis in childhood," Seminars in Arthritis and Rheumatism, vol. 26, no. 3, pp. 575-591, 1996.

[75] M. M. Schwartz, P. Simpson, K. L. Kerr, and J. N. Jarvis, "Juvenile rheumatoid arthritis in African Americans," Journal of Rheumatology, vol. 24, no. 9, pp. 1826-1829, 1997.

[76] L. A. Merlino, J. Curtis, T. R. Mikuls, J. R. Cerhan, L. A. Criswell, and K. G. Saag, "Vitamin D intake is inversely associated with rheumatoid arthritis: results from the Iowa Women's Health Study," Arthritis and Rheumatism, vol. 50, no. 1, pp. 72-77, 2004.

[77] Z. Andjelkovic, J. Vojinovic, N. Pejnovic et al., "Disease modifying and immunomodulatory effects of high dose $1 \alpha(\mathrm{OH}) \mathrm{D} 3$ in rheumatoid arthritis patients," Clinical and Experimental Rheumatology, vol. 17, no. 4, pp. 453-456, 1999.

[78] M. F. Prummel, T. Strieder, and W. M. Wiersinga, "The environment and autoimmune thyroid diseases," European Journal of Endocrinology, vol. 150, no. 5, pp. 605-618, 2004.

[79] Y. Tomer and T. F. Davies, "The genetic susceptibility to Graves' disease," Bailliere's Clinical Endocrinology and Metabolism, vol. 11, no. 3, pp. 431-450, 1997.

[80] T. H. Brix, P. S. Hansen, K. O. Kyvik, and L. Hegedüs, "Cigarette smoking and risk of clinically overt thyroid disease: a population-based twin case-control study," Archives of Internal Medicine, vol. 160, no. 5, pp. 661-666, 2000.

[81] G. Tamer, S. Arik, I. Tamer, and D. Coksert, "Relative vitamin D insufficiency in Hashimoto's thyroiditis," Thyroid, vol. 21, no. 8, pp. 891-896, 2011.

[82] S. Kivity, N. Agmon-Levin, M. Zisappl et al., "Vitamin D and autoimmune thyroid diseases," Cellular and Molecular Immunology, vol. 8, no. 3, pp. 243-247, 2011.

[83] G. E. Krassas, K. Tziomalos, N. Pontikides, H. Lewy, and Z. Laron, "Seasonality of month of birth of patients with Graves' and Hashimoto's diseases differ from that in the general population," European Journal of Endocrinology, vol. 156, no. 6, pp. 631-636, 2007.

[84] D. I. W. Phillips, D. J. P. Barker, and J. A. Morris, "Seasonality of thyrotoxicosis," Journal of Epidemiology and Community Health, vol. 39, no. 1, pp. 72-74, 1985.

[85] M. E. Spehlmann, A. Z. Begun, J. Burghardt, P. Lepage, A. Raedler, and S. Schreiber, "Epidemiology of inflammatory bowel disease in a German twin cohort: results of a nationwide study," Inflammatory Bowel Diseases, vol. 14, no. 7, pp. 968-976, 2008.

[86] F. Carbonnel, P. Jantchou, E. Monnet, and J. Cosnes, "Environmental risk factors in Crohn's disease and ulcerative colitis: an update," Gastroentérologie Clinique et Biologique, vol. 33, supplement 3, pp. S145-S157, 2009.

[87] J. H. Ooi, J. Chen, and M. T. Cantorna, "Vitamin D regulation of immune function in the gut: why do T cells have vitamin D receptors?" Molecular Aspects of Medicine, vol. 33, no. 1, pp. 77-82, 2012.

[88] J. Gilman, F. Shanahan, and K. D. Cashman, "Determinants of vitamin D status in adult Crohn's disease patients, with particular emphasis on supplemental vitamin D use," European Journal of Clinical Nutrition, vol. 60, no. 7, pp. 889-896, 2006.

[89] A. J. Joseph, B. George, A. B. Pulimood, M. S. Seshadri, and A. Chacko, "25 $(\mathrm{OH})$ vitamin D level in Crohn's disease: association with sun exposure \& disease activity," Indian Journal of Medical Research, vol. 130, no. 2, pp. 133-137, 2009.
[90] V. Nerich, E. Monnet, A. Weill et al., "Fine-scale geographic variations of inflammatory bowel disease in france: correlation with socioeconomic and house equipment variables," Inflammatory Bowel Diseases, vol. 16, no. 5, pp. 813-821, 2010.

[91] A. Ekbom, C. Helmick, M. Zack, and H. O. Adami, "The epidemiology of inflammatory bowel disease: a large, population-based study in Sweden," Gastroenterology, vol. 100, no. 2, pp. 350-358, 1991.

[92] M. A. Mendall, A. Viran Gunasekera, B. Joseph John, and D. Kumar, "Is obesity a risk factor for Crohn's disease?" Digestive Diseases and Sciences, vol. 56, no. 3, pp. 837-844, 2011.

[93] H. M. Pappa, C. M. Gordon, T. M. Saslowsky et al., "Vitamin $\mathrm{D}$ status in children and young adults with inflammatory bowel disease," Pediatrics, vol. 118, no. 5, pp. 1950-1961, 2006.

[94] P. H. A. Bours, J. P. M. Wielders, J. R. Vermeijden, and A. van de Wiel, "Seasonal variation of serum 25-hydroxyvitamin D levels in adult patients with inflammatory bowel disease," Osteoporosis International, vol. 22, no. 11, pp. 2857-2867, 2010.

[95] S. P. Jørgensen, J. Agnholt, H. Glerup et al., "Clinical trial: vitamin D3 treatment in Crohn's disease-a randomized double-blind placebo-controlled study," Alimentary Pharmacology and Therapeutics, vol. 32, no. 3, pp. 377-383, 2010.

[96] D. R. Terrell, L. A. Beebe, S. K. Vesely, B. R. Neas, J. B. Segal, and J. N. George, "The incidence of immune thrombocytopenic purpura in children and adults: a critical review of published reports," American Journal of Hematology, vol. 85, no. 3, pp. 174-180, 2010.

[97] D. Provan, R. Stasi, A. C. Newland et al., "International consensus report on the investigation and management of primary immune thrombocytopenia," Blood, vol. 115, no. 2, pp. 168-186, 2010.

[98] G. K. Schwalfenberg and S. J. Genuis, "Vitamin D supplementation in a nursing home population," Molecular Nutrition and Food Research, vol. 54, no. 8, pp. 1072-1076, 2010.

[99] W. B. Grant, G. K. Schwalfenberg, S. J. Genuis, and S. J. Whiting, "An estimate of the economic burden and premature deaths due to vitamin D deficiency in Canada," Molecular Nutrition and Food Research, vol. 54, no. 8, pp. 1172-1181, 2010.

[100] W. B. Grant, H. S. Cross, C. F. Garland et al., "Estimated benefit of increased vitamin D status in reducing the economic burden of disease in western Europe," Progress in Biophysics and Molecular Biology, vol. 99, no. 2-3, pp. 104-113, 2009.

[101] G. Bjelakovic, L. L. Gluud, D. Nikolova et al., "Vitamin D supplementation for prevention of mortality in adults," Cochrane Database of Systematic Reviews, no. 7, article CD007470, 2011. 


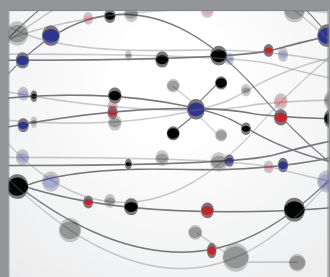

The Scientific World Journal
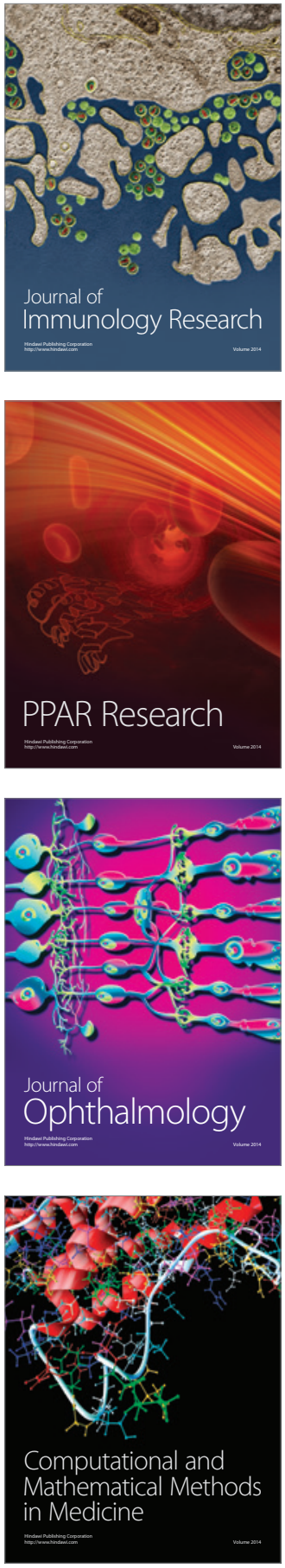

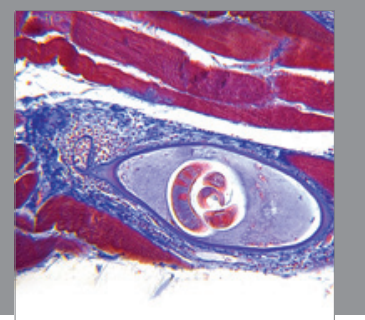

Gastroenterology

Research and Practice
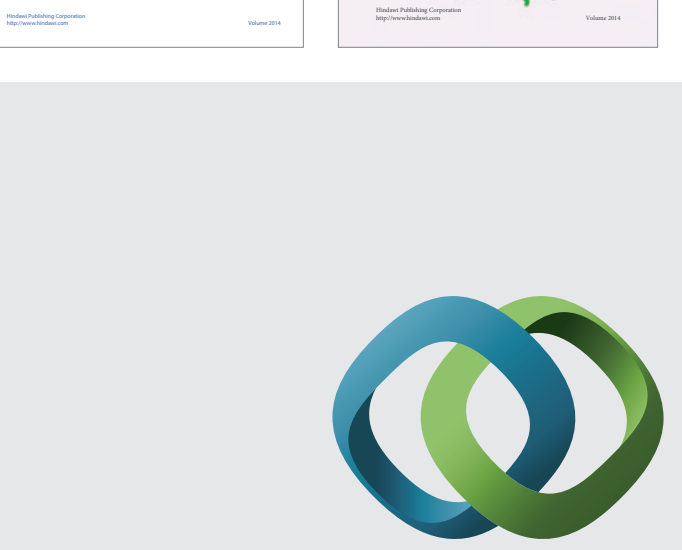

\section{Hindawi}

Submit your manuscripts at

http://www.hindawi.com
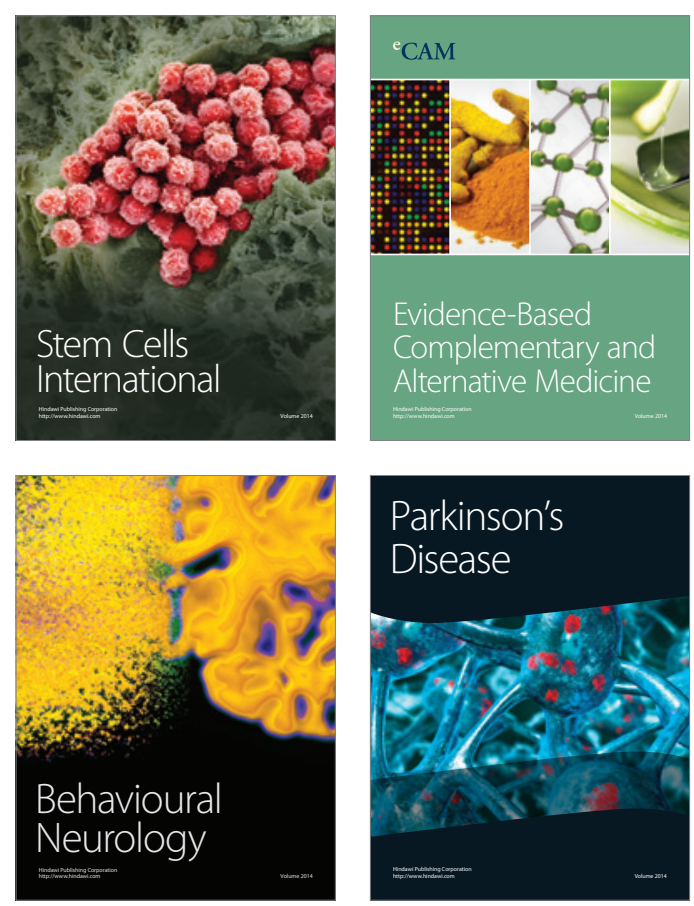

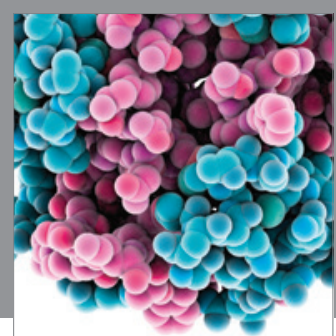

Journal of
Diabetes Research

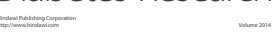

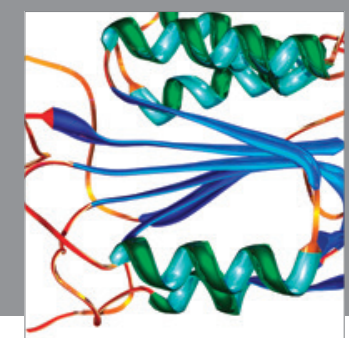

Disease Markers
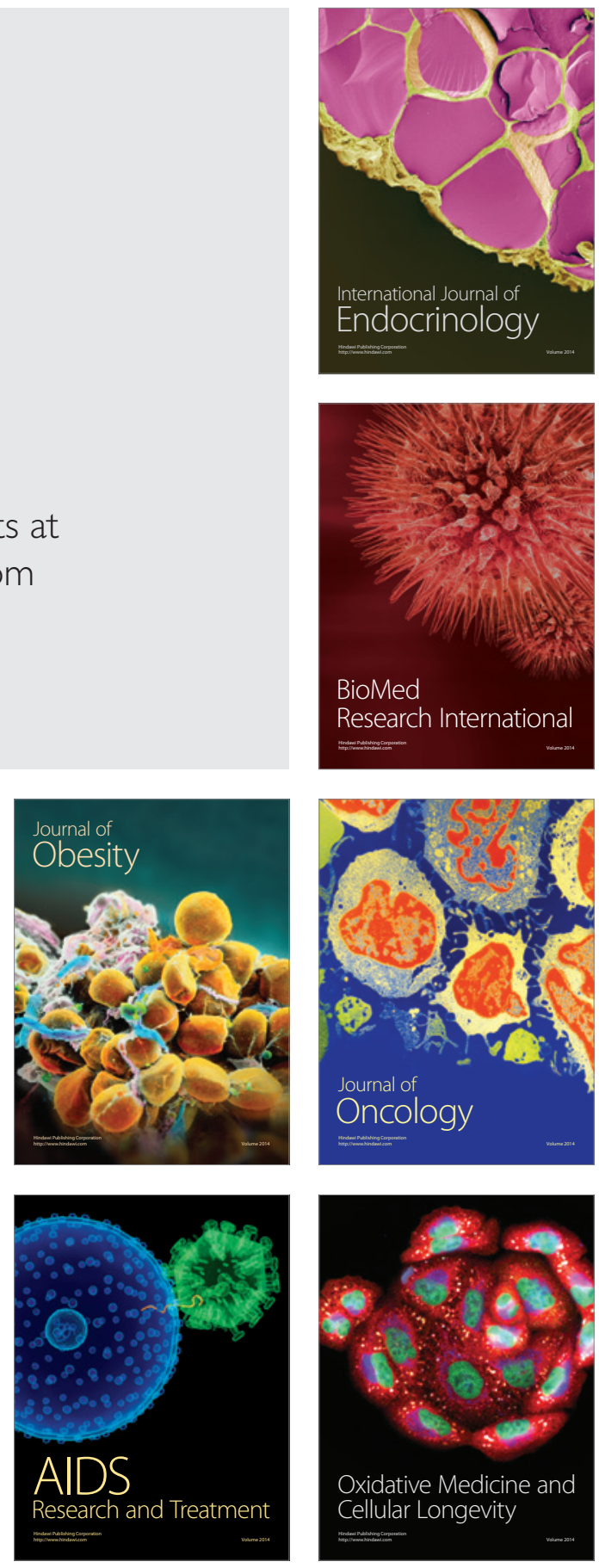